\title{
O PROFETISMO DE JOÃO MARIA NOS DISCURSOS CONTEMPORÂNEOS ${ }^{1}$
}

\author{
Tânia Welter ${ }^{2}$
}

Resumo: Este é um estudo sobre os discursos contemporâneos a respeito do Profeta São João Maria, em Santa Catarina. Partindo da noçáo de discurso como ação humana significativa, afirmo que os discursos a respeito de João Maria são ressignificados pelas pessoas a partir de sua cultura histórica, possuem temporalidade, expressam algo e são disponibilizados para outras leituras e interpretaçôes. A partir de critérios próprios, as pessoas legitimam João Maria como profeta e este se torna adequado na interpretação e, no controle da indeterminação do mundo, para anunciar e acabar com o mal, reagir contra aquilo que não está de acordo com sua cultura ou anunciar o mundo desejado.

Palavras-chave: São João Maria, Santa Catarina, profeta, discurso

Abstract: This study analyses the contemporary discourses on the divinity of the Prophet Saint João Maria, in the state of Santa Catarina, southern Brazil. Supported by the notion of discourse as significant human action, I propose that the discourses on Saint João Maria have temporality; are resignified by men and women based on their historical culture; express something and are made available for other readings and interpretations. Men and women legitimate Saint Joáo Maria as a prophet based on personal criteria and, thus, he becomes suitable in the interpretation of the world, in controlling the indetermination of the world, to announce and cease evil, to react against what goes against their culture or to announce the desired world.

Keywords: Saint João Maria, State of Santa Catarina (Brazil), prophet, discourse

\footnotetext{
${ }^{1}$ Este texto é uma versão modificada do capitulo de meu trabalho de doutorado (Welter, 2007), intitulado João Maria como profeta. Agradeço as contribuiçóes da orientadora, Maria Amélia Schmidt Dickie, e da banca examinadora, composta por Carlos Alberto Steil, Artur Cesar Isaia, Oscar Calavia Sáez e Vania Zikán Cardoso.

${ }^{2}$ Professora do Departamento de Ciências Humanas do Centro de Ciências Humanas e da Educação da Universidade do Estado de Santa Catarina (UDESC)
}

Debates do NER, Porto Alegre, ano iI, N. I7 P. II-34, JAN./Jun. 20 IO 